\title{
QUEEN'S
QNIVERSITY
BELFAST
}

\section{These Fine Lines: Locating Noncitizenship in Political Protest in Europe}

Johnson, H. L. (2015). These Fine Lines: Locating Noncitizenship in Political Protest in Europe. Citizenship Studies, 19(8), 951-965. https://doi.org/10.1080/13621025.2015.1110287

Published in:
Citizenship Studies

Document Version:

Peer reviewed version

Queen's University Belfast - Research Portal:

Link to publication record in Queen's University Belfast Research Portal

Publisher rights

(C) 2015 Taylor \& Francis.

This is an Accepted Manuscript of an article published by Taylor \& Francis in Citizenship Studies Vol 19, Issue 8, 2015, available online: http://wwww.tandfonline.com/10.1080/13621025.2015.11110287.

\section{General rights}

Copyright for the publications made accessible via the Queen's University Belfast Research Portal is retained by the author(s) and / or other copyright owners and it is a condition of accessing these publications that users recognise and abide by the legal requirements associated with these rights.

Take down policy

The Research Portal is Queen's institutional repository that provides access to Queen's research output. Every effort has been made to ensure that content in the Research Portal does not infringe any person's rights, or applicable UK laws. If you discover content in the Research Portal that you believe breaches copyright or violates any law, please contact openaccess@qub.ac.uk. 


\title{
These Fine Lines: Locating Noncitizenship in Political Protest in Europe
}

\author{
Heather L. Johnson
}

\section{Queen's University Belfast, Belfast, Northern Ireland}

\section{Correspondence}

Email: h.johnson@qub.ac.uk

Telephone: +44 (0)2890973646

Address: School of Politics, International Studies and Philosophy

25 University Square

Queen's University

Belfast, Northern Ireland

BT7 1PB

\section{Acknowledgements}

The author would like to gratefully thank Katherine Tonkiss, Tendayi Bloom and the anonymous reviewers for very helpful comments. I would also like to thank members of Refugee Protest Camp Vienna for giving of their time and stories. All errors are my own.

\begin{abstract}
Since 2012, refugee protest camps and occupations have been established throughout Europe that contest the exclusion of refugees and asylum seekers, but that also make concrete demands for better living conditions and basic rights. It is a movement that is led by migrants as noncitizens, and so reveals new ways of thinking of the political agency and status of noncitizenship not as simply reactive to an absence of citizenship, but as a powerful and transgressive subjectivity in its own right. This paper argues that we should resist collapsing analysis back into the frameworks of citizenship, and instead be attentive to the politics of presence and solidarity manifest in these protest camps as a way of understanding, and engaging, noncitizen activism.
\end{abstract}

Keywords: protest, noncitizenship, political agency, solidarity, camps 
Take a strong painkiller. Then turn the front two oven rings of your oven on and wait until they are red hot. Then lay four fingers of your right hand on the right oven ring and the four fingers of the left on the left ring.

Why you are doing this?

... "The borders that exclude me from elementary human rights, from leading a good life, lay beyond barbed wire. The border which separates people from unworthy people: these are the fine lines on my fingers." This is what you say before you press your hand on the oven. (excerpted from Leisch, February 19 2013).

The fine lines of border politics as they are lived and experienced by irregular migrants are the lines of geographical borders crossed, of fences and walls that mark immigration reception centres, and of the social borders between legal and illegal, allowed and disallowed. They are the lines of the fingerprints that are stored in the Eurodac database. They are fine lines between citizen and noncitizen and, fundamentally, they are political. They mark legitimate participation, and what might be considered threatening or troubling agency. Any discussion of migrant and noncitizen political agency grapples with these lines, and how they might be, and are, transgressed. This paper begins from such transgression, defining noncitizenship as a political status that is not the simply the absence of citizenship, but that has political content in itself. Rather than seeking an enactment of citizenship in order to understand migrant agency, the refugee protest camp movements in Europe are examples of transgressive, situated solidarity as noncitizens give us clues about how we can rethink activism and political agency within the border politics of mobility.

The following paper begins an examination of refugee and migrant protest across Europe, questioning the utility of citizenship as a guiding framework and engaging with manifestations of presence and solidarity within the politics of noncitizenship. Recent years have witnessed an expanding trend of refugee protest camps across Europe. It began in Würzburg, Germany, in March 2012 and is reflected in ongoing refugee strikes and occupations in Austria, Denmark, Turkey, Bulgaria, Greece, France and the Netherlands (Gržinić 2013). In that the protests are directly engaging the state, the movement speaks in familiar terms, making demands for legal status and for better living conditions. It has roots back through the 'no borders' protests that have persisted in Europe for over ten years as citizen-activists agitate on behalf of irregular migrants and asylum seekers moving within the ever-more restrictive European border regime. However, these emergent protests are not citizen-activist led social movements, but migrant noncitizen led practices of resistance. In the words of Refugee Camp Berlin (January 1, 2013), the protesters 'call for the recognition of the refugee movement as a political institution.' I take this call seriously here, asking 
in what ways the resistive politics of noncitizens are producing new practices of presence and solidarity that enact political claims which transgress borders and establish noncitizenship as a political subjectivity. In doing so, I am not arguing for a homogenous or unambiguous understanding of the protests; to do so would be to disregard the multiple tensions, disagreements, and differences within and between each individual protest camp. Rather, I am highlighting perceptible and emergent trends of similarity that are consciously advanced by protesters themselves to open new avenues of thinking about political agency and action. I draw on the Refugee Protest Camp Vienna and the Refugee Camp Berlin in particular, using media and public outreach material drawn largely from the movements' websites, to ask how the self-representation of the protests reveals a politics of noncitizenship that resists a simple collapse back into the frameworks of citizenship, populating the politics of migration and mobility with multiple subjectivities.

The year 2012 marked the emergence of the Refugee Protest Camps across Europe, most notably in Germany and Austria. In both cases, the protest is based in a tactic of occupation and the establishment of 'camps', founded in public places following organized marches from state immigration reception centres. In Germany, the protests were sparked in the Spring of 2012 by the suicide of a 26 year old Iranian migrant, Mohammad R., in one of the Lagers (asylum camps) in Würzburg (Hansen et al 2014, 28). Following his death, eighty fellow residents staged a spontaneous demonstration outside of the City Hall - an action which sparked protests across the country (McGuaran and Hudig 2014, 30). A massive protest march from Würzburg to Berlin was organized, ending in an encampment in Oranienplatz. Dubbing the protest a refugee strike, the protesters in Germany have undertaken rallies, marches, and hunger strikes in major cities across the country. In the fall of that year, the Refugee Protest Camp Vienna (RPCV) began with similar events. A march of over 100 refugees and supporters left from Traiskirchen reception centre, demanding freedom of movement and better living conditions for refugees and migrants, and ultimately established an encampment in the Sigmund Freud Park in front of the Votive Church, close to the University of Vienna. The occupation lasted for a month before it was forcibly cleared by police on the night of December 28, whereupon the refugees moved into the church itself. Inside, the occupation continued, and forty-five refugees embarked on a hunger strike which lasted until February 2013, with one pause in January when the refugees' health deteriorated markedly. As with the camp in Berlin, the refugee occupation has been supported by widespread action, including a march of 2500 refugees and supporters. In the spring of 2013, the RPCV was moved to an old monastery (Gržinić 
2013). The protest camp has since left the monastery, and has been located in different places throughout the city. It remains a palpable force, however, as protesters have continued to engage in a multitude of strategies and practices of protest: marches, occupations, solidarity rallies, discussion roundtables, film screenings, political speakers, and public information campaigns have numbered amongst other efforts.

The protests in Germany and Austria are echoed and reflected in similar events across Europe.

They are each important in their own contexts; they are movements of noncitizens who are claiming rights and making demands on the state that are tied directly to not only their living conditions, but to the quality of their political lives. In doing so, the protestors are asserting the legitimacy of their political voice as noncitizens. However, the movements are also explicitly and consciously connected to one another in strategy, demands, and political discourse and, I argue, they are revelatory of an understanding of political action that asserts noncitizenship as an autonomous and independent subjectivity rather than simply as an absence of citizenship. The politics of noncitizenship are thus more than an appeal to citizenship, and a demand for inclusion in its frameworks. Rather, noncitizenship is not in opposition to citizenship, but alongside it as a status that embodies powerful, transgressive political agency and new ways of interrelating in political action. In the following, I examine the tensions and temptations of collapsing noncitizen action back into citizenship frameworks, and then trace two key dimensions of migrant protest that reveal pathways towards a different understanding: the assertion of presence by breaking the isolation of refugees; and the politics of solidarity premised upon mutual responsibility. It is navigating these 'fine lines' that noncitizen activism generates new political imaginations.

\section{Noncitizen Citizenship?}

We ourselves, the refugees, make the demonstration and we are the ones who want it. It is our fight. We thank everybody for their help, but we don't allow anybody to use us. This is a selforganized struggle of and by refugees, one that needs your support, your presence on the street on Saturday (RPCV, February 13, 2013).

The protests and actions we are witnessing across Europe are unprecedented in their scale, and also in the form they are taking (McGuaran and Hudig 2014, 28). They are led by noncitizens, and are engaging in strategies and demands that contest citizenship as the only framework for understanding political action. Understanding this contestation requires that we resist collapsing back into a 
renewed emphasis on citizenship as the defining framework for political agency and participation, a challenge that has thus far proven difficult to meet in either theory or in practice.

A questioning of political subjectivity is, at its core, a struggle to define who an agent is, and how agency itself might be recognized. Citizenship, as a status, is well established as the identity that embodies legitimate (and allowable) political agency and power (Nyers 2006). Grounded in understandings of democratic or representative politics, and the bond between the 'nation' and the 'state', it is a legal status that is bounded by territory and that is clearly defined, exclusive, and exclusionary. In locating the capacity for political action in the citizen, an assumption of equivalency between 'Citizen' and 'Agent' is produced. The result is that political action or agency from outside of citizenship, by noncitizens, is seen as illegitimate, and troubling, where it is acknowledged at all (Nyers 2006). The argument about noncitizen politics ultimately becomes that noncitizens do not, or perhaps cannot, exercise political agency until they have achieved citizenship. Such a framework implies that the political work and action migrants undertake must be, and is always, expressed in terms of an aspiration to citizenship status, and that only once this status is attained can other politics occur.

I propose that the protests across Europe demand a different understanding of noncitizen political action. Noncitizenship is less grounded in territory. Instead, noncitizenship is transnational and multiple, a flexible subjectivity that embraces multiple 'categories' which are defined within shifting political contexts. It is reflective not only of assumptions and expectations laid out in state law and discourse, but of the self-representation of noncitizens themselves as they contest and use the frameworks that shape their lives and experiences. The protesters across Europe are asylum seekers, refugees, and (often undocumented) migrants, categories that may have clear definition in law, but that in practice are overlapping, simultaneous, and interchanged. Throughout the discourses that shape and represent the politics of migration, there is often an easy slippage between 'asylum seeker', 'refugee', and 'migrant' - and this is particularly the case in the language and practices of the protesters themselves. Here, individuals self-identify as one category or another at different times and places according to political context. Most often, the term 'refugee' is used in political statements, in a conscious use of and appeal to the moral and legal rights and entitlements that this category lays claim to. At other moments, 'migrant' is used to call upon a solidarity based in experiences of mobility. These self-representations are conscious, and politically savvy. They make use of the discursive content of each category in political ways to advance key demands; the 
categories are not simply given, nor are they always imposed. They are also taken, expressed, and used to advance claims from a transnational subject position of 'noncitizen'. Although each manifestation of protest is grounded in a specific context, the frameworks and assumptions that they contest are much wider. The protester's demands target not only national policy, but also the European Union (McGuaran and Hudig 2014, 28). There is a keen awareness of the ways in which migration policies and practices, such as the Dublin II Treaty and the Eurodac (the biometric database that enables the tracking of migrants via their fingerprints), operate to control the movement of migrants throughout Europe at levels beyond the nation-state. This awareness permeates the protests and contestations of noncitizens, and requires that our understandings resist a collapse back into the frameworks of citizenship and instead engage with multiple and fractured political subjectivities.

Moving beyond citizenship as the guiding framework for understanding political agency, in theory or in practice, is difficult. In many ways, this difficulty is reflects a recognition that noncitizens live in difficult and marginalized circumstances which render them particularly vulnerable to the often violent impositions of sovereign power; citizen political action, by contrast, is legitimized and validated and so is reasonably safely enacted (Johnson 2014). The vulnerability of noncitizens is particularly clear in the condition of deportability; ultimately, the noncitizen can be evicted (Oberprantacher, 2004), while freedom from deportation is one of the 'few remaining privileges' of citizens (Anderson et al. 2011, 548). Deportability 'robs individuals, particularly those without lawful migration status, of the practical ability to claim even the most basic of rights lest they bring themselves to the attention of immigration authorities' (Anderson et al. 2011, 552). This dynamic is starkly visible in the European protests, and a central demand for most movements is an end to deportations. The demands of the refugees in Vienna are particularly focused on this in response to a state crack-down on protesters in the wake of the occupation. Since 2013, Austria has undertaken a concerted campaign that focuses on the criminalization of the refugees, accusing several prominent protesters of being human traffickers and arresting, detaining, and removing them on this basis. The protest has become oriented firmly around contradicting these controlling moves of the state: ' $[t]$ he Refugee Protest Movement Vienna insists on no further deportations of refugees and no criminalization of politically active refugees who draw attention to human rights violations in their home countries' (Platzer 2013). Stopping the deportations is a clear strategy for making visibility less risky and thus creating political space for noncitizen action; without this minimal protection, so 
the argument goes, action simply is not taken. The recognition of vulnerability can quickly become an assumption that agency itself is never enacted - or cannot be enacted - because it is too dangerous. Agency becomes unexpected (Oliveri 2012, 799). The 'fine lines' that distinguish differences between political statuses constrain what kind of politics can legitimately occur, or even be seen and heard.

It is very clear that migrants, noncitizens, do undertake political action. Their ongoing participation and engagement is well documented and described throughout critical literature (cf. De Genova 2010; Johnson 2014; McNevin 2006; Nyers 2006; Rygiel 2011). Reflecting on circumstances in Italy, Oliveri sees migrant protest as potentially re-inventing the premises and conditions of being political $(2012,795)$. Protesters in Italy, he writes, 'collectively demonstrated that it is possible to stand up and ask for respect even when you live under the continuous risk of being deported' (Oliveri 2012, 794). These politics break the Citizen-Agent assumption. Nevertheless, efforts to understand this break, and to engage with noncitizens as agents, often return to citizenship itself as a framework, and utilize its ideas and norms to understand agency in other forms. Rygiel writes:

It is useful, I think, to theorize migrant struggles in terms of citizenship because the language of citizenship invokes agency with respect to subjects who are frequently depicted in the popular imagination, media, and government policy as being something other than political beings (2011, $6)$.

In this, she draws attention to the ways in which migrants assert themselves as political subjects by making claims against certain perceived injustices and inequalities and through collective action (Rygiel 2011, 6). Citizens are not the agents here, but citizenship remains the discourse and framework through which agency and voice are understood.

One of the most effective examples of this rethinking of political agency is Isin's 'acts of citizenship' (2008). Isin argues that an "act" is distinct from "action" in that it represents a challenge to "habitus" - the ways of thought and conduct internalized by members of society over the long term $(2008,15)$. It is a rupture in the given $(25)$, and produces actors who both create and effect change as 'activist citizens' (38). The 'citizen' is thus redefined away from a legal status to a conceptualization driven by action as subjects actively constitute themselves. Citizenship becomes something other than an exclusive, bounded identity, and is rendered emergent, accessible (in theory) to anyone regardless of actual legal status. This analysis is easily applied to the migrant protests. The demands of the protesters are articulated in terms of rights, which they claim entitlement to despite legal refusals and a lack of status. They are thus demands for recognition that 
disrupt assumptions about citizens as the only figures able to enact or claim rights, and so as the only form of political agent. Such demands are 'acts' that shift the normal political order to include a subjectivity found outside of formal citizenship.

Isin's 'acts of citizenship' emphasize the act rather than the actor and displace status categories as the determinant of potential agency. As Oliveri $(2012,799-800)$ argues, this framework focuses on the self-constitution of an actor provided with autonomous political agency. Self-constitution is significant, as it enables an understanding of agency that emanates not from the state, but from the individual; state-defined status is no longer the necessary criteria for political action. However, even if citizenship is defined in this way through participation and contestation, the political content of agency remains framed by citizenship. There remains an assumption that the achievement of citizenship, even an 'activist citizenship' enacted by unauthorized agents, is the goal. Citizenship is a difficult paradigm to escape, even if it is stretched and adapted.

As much as scholars struggle to escape from citizenship as the defining framework for action, so too do the protesters themselves. The noncitizen protests are always already navigating a tense and contradictory relationship with citizenship (Oliveri 2012). Within the articulated demands of the migrants themselves, citizenship is simultaneously contested in fundamental ways, while also demanded as a right in itself. For Tyler and Marciniak '[c]itizenship is a site of struggle within these protests: it is both the goal which many immigrant protestors are striving to achieve and the regime of exclusion which they are protesting against' $(2013,153)$. They write: 'inevitably, one of the main strategies of migrants and pro-migrant activists is to demand the rights of citizenship, however, problematic or precarious this citizenship may have become' $(2013,146)$. As an exclusive identity, citizenship represents, and in many ways defines, the rigid system of bordered nation-states that creates the conditions of exclusion that the protests are contesting. However, in relating demands for rights to citizenship status, or in making appeals for protection to the state, this system is (potentially) legitimized (Hansen et al 2014, 53). Many of the protester's demands are for membership, for inclusion, and for recognition, all of which in one way or another are an appeal to and for citizenship. Many of the public statements of the Berlin refugee protesters are key illustrations of this simultaneous repudiation of citizenship frameworks and an appeal to the state that invokes membership. In a statement from the hunger strikers in November 2014, for example, they appeal to human rights as universal rights exceeding state restrictions: 'we will strike till we reach our freedom. We want to have basic human rights, we are not only demanding a secure life, 
we are demanding to be treated as humans, to have rights as free persons' (Berlin Refugee Strike November 2014). In the same statement, however, they make a direct appeal to state representatives as representatives, in an appeal to membership: '[i]f you, Emilia Müller, minister of social affairs, and you, Joachim Heuman, minister for inner affairs think the Lager-system is human, we are asking from you to bring all German society to the Lagers we have to live in, or bring us into this society' (Berlin Refugee Strike November 2014).

It is clear that in both theory and practice - in both scholarly engagements with migrant politics, and in actual migrant political movements - there is a tension between a desire to contest the equivalence of the Citizen-Agent, and the pragmatic use of the frameworks and concepts of citizenship to express key political demands. It is an open question whether migrant protest should be interpreted as a re-imagining of citizenship away from a statebased paradigm towards something like 'global citizenship', or whether these protests enable forms of politics that 'exceed or refuse to be a politics of citizenship at all' (Tyler and Marcianiak 2013, 154). As Hindess (2004) argues, it is not at all clear whether a return or reinvigoration of citizenship is a productive way of accessing emergent forms of political agency. Hindess puts out a clear call to unsettle the valourization of citizenship as a divisive regime built upon exclusivity which, he argues, embeds a negative view of other ways of life $(2004,306)$. For Papadopoulos and Tsianos, ' $[t]$ he more one tries to support rights and representation through citizenship, the more one contributes to the restriction of movement' $(2013,187)$. To apply the framework of citizenship to noncitizen action risks missing key elements of the politics that are being articulated within noncitizen protest and engagement. Within such 'acts' migrants find a voice on their own terms, demanding an equality of place that is excessive of a return to citizenship and that requires new frameworks for political action. As Papadopoulos and Tsianos argue,

\footnotetext{
Migrants' politics develop their own codes, their own practices, their own logics which are almost imperceptible from the perspective of existing political action: firstly, because we are not trained to perceive them as 'proper' politics and, secondly, because they create an excess that cannot be addressed in the existing system of political representation (Papadopoulos and Tsianos 2013, 188).
}

In the somewhat dry words of Clifford Aghator (7 December, 2012), a refugee protester in Refugee Protest Camp Vienna, '[t]he refugees and asylum seekers alike are not entirely idiots or illiterates who do not know their rights, or who do not recognize when their rights are being infringed upon.' Gržinić (2013) argues: ‘[t]he refugees broke the predetermined space of politics in which only 
predetermined actors - let's say citizens - have visibility and are taken seriously when asking for democratic rights.' They have, in her words, 'repoliticized' and 'rearticulated' the space of Europe in a way that forces the citizen-based organizations and individuals who support them to reorganize their own struggles, adapting and responding to the refugees as active subjects rather than as objects of activism. The refugees are themselves activists, and not simply the issue/object around which citizen-activists organize. They are not simply citizens in another guise; they are subjects in themselves, outside of the 'normal' framework. Citizenship is a paradigm that is built fundamentally on exclusion and othering, upon the lines that divide. In translating noncitizen agency into a framework that remains described by citizenship, we lose the capacity to understand and engage noncitizenship as a political subjectivity that exists in an autonomous way. In the remainder of this paper, I examine two dynamics perceptible in the European protest movements which reveal potential ways to engage with noncitizenship as a subjectivity in itself: the assertion of presence; and the active practice of a politics of solidarity.

\section{Presence}

\footnotetext{
We refugees are fleeing from different reasons from our homecountries (sic). We are forced to leave so much loved behind: Our home land, our culture, our businesses and normal lives. We miss our families. We miss our children. Our friends. And we also miss those streets in which we played in our childhood. We lost a lot of family members in war, and also them, we miss so much.

Every refugee leaving the homecountry (sic) is thinking the same: How can I get a legal status and start a normal and safe life in another country? (RPCV February 24, 2014).
}

At the centre of the protests that are emerging across Europe is the very specific tactic of occupation. The establishment of protest 'camps' situates the protest in a local context in ways that are highly visible, fixing the excluded noncitizen as quite firmly 'here'. In contesting the isolating and exclusionary policies of states, which require that migrants live in immigration reception centres or in remote, pre-selected housing, the protest camps directly engage a politics of fixity and location, contesting the monopoly citizenship seemingly exercises over presence, over being 'here'.

Citizenship, grounded in territory, links being 'here' - or, importantly, being 'allowed' to be here with being a political subject. In doing so, the framework of citizenship equates legal status with belonging, and interposes these as the necessary criteria for being present - and so for being seen, heard, and recognized. In contesting the isolation of detention and reception centres, in asserting the camp space as a place 'here' and not as a place apart, the refugee protesters are challenging these 
criteria and re-taking presence. They are contesting citizenship as the necessary qualification for being 'here', and so for speaking and participating. In doing so, they are relocating a different subjectivity in presence, populating the 'space' of society with subjects that are in addition to the citizen.

A spatial analysis of occupation draws attention to the ways in which migrants and refugees coming together in a particular place is manifested politically. Occupation as a political strategy of resistance is about the subversion of public space, and its re-appropriation. As Bassett argues, it creates 'inbetween' spaces that are never entirely outside of the police space, but that materialize people power through subverting the 'normal distribution' of police spaces $(2014,893)$. The protest camps are manifested in direct contestation to the state-built 'asylum camps' and immigration reception centres that are designed to isolate and contain migrants. These state camps are spaces designed to control and limit noncitizen political agency, and to exclude migrants from the body politic; they are spaces of exception, in the theories of Giorgio Agamben (1998), which render individuals as 'bare life' without political meaning. The protest camps challenge this exclusion through the assertion of a political voice that is manifest not in an appeal to citizenship, but in a visible presence.

Expressions of migrant or noncitizen agency within a camp space are described and engaged with most clearly through the literature which addresses 'autonomous migration.' Scholars in this tradition emphasize not an integrationist agenda (where noncitizens are advocating for inclusion as citizens), but the agency of migrants themselves as it is manifested through cross-border mobility. Agency is thus founded not in an appeal to citizenship, but in mobility itself. Mezzadra argues that autonomy means 'looking at migratory movements and conflicts in terms that prioritize the subjective practices, the desires, the expectations and the behaviours of migrants themselves' (Mezzadra 2011,121). This means that there is an attempt to see migration not simply as a response to necessities, be they political, economic, or social, but as a constituent force in the formation of the polity that has the capacity to develop its own logics, motivations and trajectories (Papadopoulos and Tsianos 2013, 184).

The analysis undertaken by autonomous migration scholars who investigate border camps is helpful in our understanding of the role the protest camps play in expressions of noncitizen agency. Mountz argues that they are spaces where people wait, but that they are also spaces where migrants organize, network, and speak out $(2011,383)$. The camp can therefore be seen as a space of 
community (Rygiel 2011), and so they directly challenge the abjection presented in the camp-asexception formulation. Crucially, however, Rygiel also points out that an important component of the political action encompassed by these camps is that individuals ultimately leave $(2011,15)$. Noncitizens remain in motion.

The focus on mobility in this literature thus privileges movement over presence, which does not effectively capture one of the key logics of the European protest camps: an assertion of occupation of space. These protests, while grounded in a politics of mobility, are about staying, and about using situatedness and location as resources for enacting political subjectivity. One element that distinguishes the protest camps from the border camps is that they are not simply staging areas for further mobility. They are instead active claims against the state that assert a presence which, inasmuch as it is unauthorized, is also incontrovertible. As De Genova $(2010,103)$ observes about the undocumented migrant protests in the United States, such claims to presence, to being 'here', are not demands as much as they are audacious statements of fact that assert a radical, open-ended migrant agency.

Presence is asserted by the protest camps first and foremost in the contestation of the isolation imposed upon asylum seekers by European states. As one migrant in Vienna declared during a press conference in March 2013, marking the move from the Votive Church to the Servite Monastery, the protesters were determined that their new home would not be a small 'Traiskirchen' (a 'refugee camp') that isolates refugees from society (RPCV March 4, 2013). Rather, the refugees in Vienna placed visibility at the centre of action - despite the heightened risks of deportation such exposure was likely to produce. Hansen, Falkentoft and Rode argue that by using 'visibility and political agency in itself, [the camp] is a strategy breaking with the security problem of exclusion and otherness' (Hansen et al 2014, 64). Similarly, Nair argues that the protest camps are a 'performance of resistance to oppression through the bodily occupation in, and passage through, public spaces, in defiance of the political invisibility that legal and state structures impose on them' (2012, 784). Moreover, this visibility is understood to actually counter the heightened vulnerability that migrants experience. As a refugee in Vienna stated on 'Refugee Support Day', November 4, 2013, 'it is essential for us to stay public and visible, otherwise our movement will die and we will be deported' (RPCV November 2, 2013). The summer of 2013 saw the deliberate practice of visibility applied beyond the occupations themselves. 'From July till August 2013, we will go out to public places, show ourselves and call everyone, including representative people from Austrian politics and civil society, to come and listen 
to our demands for solutions' (RPCV July 12, 2013). Occupation as a political technique of resistance is about fixing the noncitizen inside and here, and their continued presence depends upon the claiming and use of space.

As in Vienna, breaking the isolation of refugees is a key political stake in the German actions. At the core of the movement is the campaign against the policy of mandatory residence, Residenapflict, which bans asylum seekers from travel within Germany. Other demands focused on the shutdown of the Lagers, an end to deportations, and the granting of residence permits for asylum seekers (Hansen et al 2014, 28). The protesters stated:

We, refugees from various camps in Germany, united our local actions and set off to Berlin. Starting from Würzburg, we covered the distance of $600 \mathrm{~km}$ in about a month. Because of our visits to the refugee camps along the route, we were able to expose the isolation of the refugees, and invited them to leave their camps and join our march... We declare that we intend to fight the laws and policies that violate our freedom and dignity (Refugeecamp Berlin, January 1 2013).

The statement issued on the occasion of the hunger strike in Munich in November 2014 asserted:

Lagers/camps are prisons for us. Residenzpflicht/residential obligation is a sign of slavery.

Restrictions of work and study are made to divide us from society and to force us to be in inhuman situations. Deportations by Dublin regulations are a sign of political organized policy from EU countries.

At this point we want to say we are not poor refugees, OUR RIGHTS HAVE BEEN STOLEN (November 23 2014).

Again, in presence a political right is claimed: the right to be seen, to be here.

In the protest camps, the assertion of being 'here' grounds claims of rights and political voice not in citizenship, but in physical presence. To contest isolation, and to claim belonging in this sense is not a claim to citizenship as 'the' territorially relevant identity, but to bypass citizenship and to claim political agency on the basis of being located, present, and here.

\section{Solidarity}

Our position is very clear: We do not talk about facilities, about own places, but about legal status and about our struggle. This is the time to share responsibilities. You do your job, outside, on your side, and I do my job, inside. You provide a table, I talk to the prime minister, to the chancellor. This is the European Union. They say they work for a peaceful world, we support this! Because we are also part of this world, and our role is very important (RPCV, May 3 2013).

While asserting presence bypasses citizenship as the defining mediator for expressing political agency, the politics of solidarity that are found in and across the refugee protest camps express 
important ways of thinking through political relations not simply apart from citizenship, but between citizen and noncitizen subjectivities. These relations are a conscious goal of the protests, which have actively adopted 'noncitizen' as a meaningful identity. In March 2013, the Refugee Struggle Congress was organized by the Aktionskries unabbängig protestierender Flüchtlinge (Action group of independently protesting refugees), in Germany. Throughout the conference, the concept of noncitizen was debated at length and was consciously used as a political identification, as a way of asserting the political subjectivity of the protesters, and as a denial of their position as recipients of charity (McGuaran and Hudig 2014, 31). Rather than seeking a solidarity which asserts the 'right' of the citizen to use her privilege to speak on behalf of the refugee or to create a space for the refugee - both marking the citizen as the active subject - citizen/noncitizen solidarity in the refugee protest camps has emerged as both a demand, and as a mutual responsibility within the politics of resistance. Noncitizens are outside of the traditional solidarity and community that is at the normative heart of citizenship (Kofman 1995, 123); in the present-day migrant protests, the response of protesters has to been redefine and reinvent solidarity rather than to demand inclusion in already existing, but seemingly inadequate, citizenship relations.

This redefinition of solidarity and political relations rests within a rethinking of how representation operates, and so of where demands are directed and to whom they are articulated. As Papadopoulos and Tsianos note, it is citizenship that regulates the relation between rights and representation (2013, 181). It is citizens who are entitled to representation, and this is the mechanism through which rights claims are made. As Arendt (1951) has convincingly argued, rights are meaningless without the 'right to have rights', which is activated through the mechanisms of citizenship that enable individuals to makes demands upon a state. However, within the migrant protests, rights claims are being made by noncitizens, and in ways that are meaningful and are shifting political relations; the connection Arendt asserts between citizenship and the 'right to have rights' is being contested, but it has yet to be fundamentally broken. A puzzle emerges about how noncitizens can advance rights claims without making appeals to citizenship. In the relations of solidarity that are articulated throughout the protest movement, a partial answer can be found: the relationship between citizens and noncitizens is founded upon a mutual responsibility that makes use of citizenship without making it a precondition for all political action.

This understanding of solidarity requires a sustained, ongoing, and dynamic interaction across the fine lines of status that demarcate the boundaries of citizenship. Franke writes: 
At stake is not access to recognition and protection but, instead, access to debate and the willingness to receive the challenges of others. At stake is the right to be political, not governed (2011, 51, emphasis added).

Such solidarity is rooted first and foremost in direct contact and conversation. As one refugee in Vienna states, '[i]t is important to be in contact with normal people' (RPCV May 3, 2013). Through this contact, the relations between citizen and noncitizen are understood to also comprise obligations. In response to a series of deportations in December of 2013, for example, an article was released by Refugee Protest Camp Vienna stating:

To bring this inhumane system to an end and to stop deportations, we have to organize and to take to the streets. We have to put pressure on those in power, but at the same time get active ourselves. We are all responsible (RPCV December 14,2013).

The article is signed with the statement: ' $\mathrm{t}]$ he authors of this article have different statuses in Austria, we are people with and without papers, some have refugee-background and some don' $t$ ' (RPCV December 14, 2013). In many of the press releases and reports released by the collectives in all locations, this sense of locating the struggle across legal status categories is explicit: 'it's not about the victims - it's against all of us, against the repression of political protest' (RPCV June 17 2014). The refugees in this way understand themselves not as simply asserting their own rights to political agency and participation, but as protecting this space of resistance for all people - noncitizens, but also citizens. Further, the roles of 'refugee' and 'supporter' are blurred. A refugee being interviewed during the occupation of the Votive Church in Vienna was clear that he identified himself as both a refugee and a supporter - that his work in the protest and in the occupation was also about standing in support of other refugees and other noncitizens, in Vienna and elsewhere. This introduces a multiplicity of identities in the political subjectivity of the noncitizen, a plurality that destabilizes otherwise fixed 'roles' in activism. Solidarity, as it emerges from a practice of politics that asserts noncitizenship as an independent, and not contingent, subjectivity places at its heart a responsibility to act for both the noncitizen and for the citizen, expanding the normative political community to include multiple categories.

The efforts in the protest movement to organize across the divide between citizen and noncitizen are clear, and it is important to note that they are noncitizen led. In June of 2014, a post on the Refugee Protest Camp Vienna website announced:

As it become rather quiet around refugee and anti-deportation protests in the last months, it is high time for people who want to act against the european border regime and the austrian asylum system to connect. Thus, we want to meet regularly again, in order to get to know each other and 
act together for freedom of movement and equal political and social rights for everybody (RPCV

June 20, 2014).

Similarly, the protesters in Berlin called a meeting in November 2014 'to create the structure we need to give efficiency to our struggle' (Berlin, November 2014). The proposed topics for the meeting included bringing groups together into a common strategy, establishing a regular and permanent assembly of all refugee groups in Berlin, and communication strategies amongst the group, and with the wider society (Berlin, November 2014). The work that is being done locates the practice of solidarity in the everyday lives of participants, both citizen and noncitizen, and is as much about relations within the community as it is about relations with the state.

This founding of solidarity in relations of mutual responsibility rejects traditional, often paternalistic, interactions across the citizenship divide. Instead, solidarity is a demand. During a public speech following the Refugee Protest Camp Vienna's symbolic rejection of the Ute Bock Prize for Moral Courage in January 2013, one of the refugees sent out a challenge: 'You are citizens that support our demands. Therefore, why don't you demand that your political representatives - who you, as citizens, have elected - change this unbearable situation?!' (Gržinić 2013, 3). This statement is powerful. It expresses a desire for solidarity that positions noncitizens as capable of making demands not only of the state, but of one another and of their citizen supporters. This is therefore also a call for a relationship of equality that recognizes the different political positions of power and of vulnerability. It recognizes that citizens have the power to operate within traditional politics of representation, but also that with this power comes a responsibility to use it in support of noncitizens, who, despite their vulnerability, nevertheless have the capacity to articulate their own demands and to be seen and heard. The call is widespread: "[e]veryone living in the "western world" is responsible for not looking away and showing solidarity', declared the Refugee Protest Camp Vienna in December of 2013, in response to a series of deportations. Such statements are not simply rhetorical, and the collective has not hesitated to be critical of actions (or failures to act) that are understood to contravene their expectations of support.

\footnotetext{
We call for active resistance against Austrian authorities who threaten refugees with deportation! And we want to criticize sharply the role of Caritas which is running a lot of the refugee houses in Vorarlberg and other areas from where refugees are picked for deportation and doesn't show any visible protest or practical solidarity with the victims of deportation (RPCV December 14 2013).
}

In standing up to be heard, the refugees have exposed themselves to state and police crackdown that may have serious consequences. The solidarity called for is a solidarity that recognizes and respects their action as political participation, and as a radical demand for change. It enables a relationship of 
mutual support and protection that uses the security of the citizen, but does not reduce or subordinate the power of the migrant. Such solidarity is not easy; it requires a rethinking of protection, equality, and of protest itself.

\section{Fine lines}

"The borders that exclude me from elementary human rights, from leading a good life, lay beyond barbed wire. The border which separates people from unworthy people: these are the fine lines on my fingers" (Leisch, February 19 2013).

Tyler and Marcianiak, write: ' $[t]$ he radical potential of immigrant protests precisely resides in the ways in which migrants organize and act despite their lack of access to the rights and protections of citizenship' (2013,149-150). The refugee and migrant protests that have emerged in Europe, and that continue to contest both state and European policies and frameworks are significant in their durability, and their visibility. The protesters are demanding a reconfiguration of not only the migration frameworks of the borders of Europe, but also of the ways in which the nation-citizenstate nexus determines our notions of political agency and action. In asserting presence out of mobility, and in shaping a demanding solidarity that entails a relationship of mutual responsibility across the citizenship divide, the protesters are exhibiting a noncitizenship that is a political subjectivity in its own right, and that opens up possibilities for rethinking and reimagining political action. It asserts noncitizenship as autonomous and independent rather than simply a status marking an absence of citizenship. The politics of noncitizenship are more than a demand for inclusion in citizenship frameworks, and instead represent a powerful political agency that calls upon new and dynamic political relations across multiple lines that divide.

'Why you are doing this?' asks the poem with which this paper began. Such a question is worth asking beyond the act of the burning of fingerprints, a violent and embodied act of resistance against the border regimes of Europe. The answer lies in the relationships across geographical boundaries, and across the fine lines between citizen and noncitizen. In recognizing political action and actors that are beyond our current citizenship-based framework for understanding agency, borders are being crossed in ways that are both present and in solidarity, and are powerful in their imagination of a coming politics. 


\section{Bibliography}

Agamben, Giorgio (1998). Homo Sacer. (Stanford: Stanford University Press).

Anderson, Bridget, Matthew J. Gibney and Emanuela Paoletti (2011). "Citizenship, deportation and the boundaries of belonging" Citizenship Studies 15(5): 547-563.

Bassett, Keith (2014). "Rancière, politics, and the Occupy movement" Environment and Planning D: Society and Space 32: 886-901.

Berlin Refugee Strike (2014). 'Hungerstrike of refugees in Munich', November 23. http://oplatz.net/2014/11/23/hungerstrike-of-refugees-in-munich/\#more-5601.

De Genova, Nicholas (2010). “The Queer Politics of Migration: Reflections on 'Illegality' and Incorrigibility" Studies in Social Justice 4(2): 101-126.

Franke, Mark F.N. (2011). "The unbearable rightfulness of being human: citizenship, displacement, and the right to not have rights" Citizenship Studies 15(1): 39-56.

Gržinić, Marina (2013). "A Refugee Protest Camp in Vienna and the European Union's Processes of Racialization, Seclusion and Discrimination" e-flux journal 43 (March).

Hansen, Nanna Kathrine, Maja Felicia Falkentoft, and Carsten Baltzer Rode (2014). "Desecuritizing Migration: the Case of the Berlin Refugee Strike" Special Project (Roskilde Universitet: Institut for Samfund og Globalisering).

Hindess, Barry (2004). "Citizenship for All" Citizenship Studies 8(3): 305-315.

International Coalition of Undocumented, Migrants, Refugees and Asylum Seekers (CISPM) (2014). 'Declaration by International Coalition of Undocumented, \#Migrants, \#Refugees and \#Asylum Seekers', The VOICE Refugee Forum Germany, November 26. http://thevoiceforum.org/node/3790.

Leisch, Tina (2013). 'Imagine being a refugee/Stellen Sie sich vor, Sie wären Flüchtling', February 19. http://refugeecampvienna.noblogs.org/post/2013/02/19/imagine-being-a-refugeestellen-sie-sich-vor-sie-waren-fluchtling/.

Isin, Engin (2008). "Theorizing Acts of Citizenship" in Engin Isin and Greg Nielson, eds., Acts of Citizenship (London: Zed Books): 15-43.

Johnson, Heather L. (2014). Borders, Asylum and Global Noncitizenship: The Other Side of the Fence (Cambridge: Cambridge University Press).

Kofman, Eleonore (1995). "Citizenship for some but not for Others: spaces of citizenship in contemporary Europe" Political Geography 14(2): 121-137.

Leisch, Tina (2013). 'Imagine being a refugee/Stellen Sie sich vor, Sie wären Flüchtling', February 19. http://refugeecampvienna.noblogs.org/post/2013/02/19/imagine-being-a-refugeestellen-sie-sich-vor-sie-waren-fluchtling/.

McGregor, JoAnn (2011). "Contestations and consequences of deportability: hunger strikes and the political agency of non-citizens" Citizenship Studies 15(5): 597-611.

McGuaran, Katrin and Kees Hudig (2014). "Refugee Protests in Europe: fighting for the right to stay" Statewatch Journal: reflections on the state and civil liberties in Europe 23 (3/4): 28-32.

McKay, Lauren and Margaret Childs (2013). "Seeking Sanctuary: Refugees Protest Asylum Law" The Vienna Review, January 31.

McNevin, Anne (2006). "Political belonging in a neoliberal era: The struggles of the sans-papiers" Citizenship Studies 10(2): 135-51.

Mezzadra, Sandro (trans. Rodrigo Nunes)(2011). "The gaze of autonomy: Capitalism, migration and social struggles" in Squire, Vicki, ed., The Contested Politics of Mobility: Borderzones and irregularity (London: Routledge): 121-142.

---- and Brett Neilson (2003). "Border as Method, or, the Multiplication of Labor," Transversal: 
EIPCP multilingual webjournal. [online] Available at: http://eipcp.net/transversal/0608/ mezzadraneilson/en.

Millner, Naomi (2011). 'From 'refugee' to 'migrant' in Calais solidarity activism: Re-staging migration for a future politics of asylum" Political Geography 30: 320-328.

Mountz, Alison (2011). "Where asylum-seekers wait: feminist counter-topographies of sites between states" Gender, Place and Culture: A Journal of Feminist Geography 18(3): 381-399.

Nair, Parvati (2012). "The body politic of dissent: the paperless and the indignant" Citizenship Studies 16(5-6): 783-792.

Nyers, Peter (2006). Rethinking Refugees: Beyond States of Emergency. (New York: Routledge).

Oliveri, Federico (2012). "Migrants as activist citizens in Italy: understanding the new cycles of struggles" Citizenship Studies 16(5-6): 793-806.

Oberprantacher, Andreas (2014). "Holey Union: Contested European Frontier Zones" Journal of Conflictology 5(2): 72-80.

Papadopolous, Dimitris, Niamh Stephenson and Vassilis Tsianos (2008). Escape Routes: Control and Subversion in the $21^{\text {st }}$ Century. (London: Pluto Press).

---- (2013). "After Citizenship: autonomy of migration, organisational ontology and mobile commons" Citizenship Studies 17(2): 178-196.

Platzer, Michael (2013). Report to the United Nations: Deportation of Protestors against Inbumane Conditions in Refugee Camps and Asylum Procedures in Austria. [online] Available at: http://refugeecampvienna.noblogs.org/post/2013/08/25/report-to-the-un-deportation-ofprotestors-against-inhumane-conditions-in-refugee-camps-and-asylum-procedures-inaustria/

Refugeecamp Berlin Info (2013). 'Why We Marched to Berlin and Why We Continue Our Resistance', January 1. http://refugeecampberlininfo.tumblr.com/.

Refugee Protest Camp Vienna (2014). 'Podiumsdiskussion und Soli-Party', July 12. http://refugeecampvienna.noblogs.org/post/2014/06/12/podiumsdiskussion-und-soliparty-its-not-about-the-victims-its-against-all-of-us-against-the-repression-of-politicalprotest-17-06-2014/

---- (2014). 'Solidaritätserklärung gegen die Kriminalisieming von Migrantinnen und Refugees/ Solidarity statement against the criminalisation of Migrants and Refugees', February 24. http://refugeecampvienna.noblogs.org/post/2014/02/24/solidaritatserklarung-gegen-diekriminalisierung-von-migrantinnen-und-refugees/

---- (2013) 'New wave of deportations from Austria - get active for concrete solidarity to stop deportations', December 14.

http://refugeecampvienna.noblogs.org/post/2013/12/14/new-wave-of-deportations-fromaustria-get-active-for-concrete-solidarity-to-stop-deportations/

---- (2013). 'Refugee Support Day: Monday, 4/11/2013', November 2. http://refugeecampvienna.noblogs.org/post/2013/11/02/refugee-support-day-monday4112013/

---- (2013). 'Open Doors at the Refugee Protest', October 16. http://refugeecampvienna.noblogs.org/post/2013/10/16/willkommen-im-refugee-protestwien-welcome-to-the-refugee-protest-vienna/

---- (2013). 'Month of visibility - we still demand our rights! We need a solution!', July 12. http://refugeecampvienna.noblogs.org/post/2013/07/12/month-of-visibility-we-stilldemand-our-rights-we-need-a-solution/

---- (2013). 'Interview: Die Forderung nach eirem normalen Leben... - The demand for a normal 
life...', May 3. http://refugeecampvienna.noblogs.org/post/2013/05/03/interview-dieforderung-nach-einem-normalen-leben-the-demand-for-a-normal-life/

---- (2013). 'AUDIO: [own words] Striking refugees now at Servite Monastery: Press Conference by refugees, church and Caritas on March 4, 2013', March 4.

http://refugeecampvienna.noblogs.org/post/2013/03/04/audio-o-ton-protestierenderefugees-nun-im-servitenkloster-pressekonferenz-von-refugee-kirche-und-caritas-am-4-marz2013/

---- (2013). 'Speech on occasion of the protest songcontest at the theatre Rabenhof, February 13. http://refugeecampvienna.noblogs.org/post/2013/02/13/speach-on-occasion-of-theprotestsongcontest-at-the-theatre-rabenhof/

---- (2012). 'Asylwerber am Wort: Wie es uns so geht/A Statement of Clarification Coming from the Camp', December 10.

http://refugeecampvienna.noblogs.org/post/2012/12/10/asylwerber-am-wort/

Rygiel, Kim (2011). "Bordering solidarities: migrant activism and the politics of movement and camps at Calais" Citizenship Studies 15(1): 1-19.

Tyler, Imogen and Katarzyna Marciniak (2013). "Immigrant Protest: an introduction" Citizenship Studies 17(2): 143-156. 